\title{
Providing Care for Underserved Patients: Endodontic Residents', Faculty Members', and Endodontists' Educational Experiences and Professional Attitudes and Behavior
}

\begin{abstract}
Marita R. Inglehart, Dr. phil. habil.; Brady K. Schneider; Patricia A. Bauer, D.D.S., M.S.; Maneet M. Dharia, D.D.S.; Neville J. McDonald, B.D.S., M.S.

Abstract: In the United States, access to dental care is often challenging for patients from socioeconomically disadvantaged and/ or minority populations and for patients with special health care needs (SHCN). The objectives of this study were to a) explore endodontic residents', endodontic faculty members', and private practice endodontists' perceptions of their education about treating underserved patients, along with their related attitudes and behavior, and $b$ ) to determine how their educational experiences were related to their attitudes and behavior concerning these patients. It was hypothesized that the quality of educational experiences related to these issues would correlate with the providers' professional attitudes and behavior. Methods: Survey data were collected from seventy-eight endodontic residents, forty-eight endodontic faculty members, and seventy-five endodontists in private practice. Results: The residents reported themselves being better prepared to treat these patients than did the endodontists in private practice. The residents and faculty members had more positive attitudes towards patients with SHCN, developmental disabilities, and pro bono cases and were more confident when treating patients with developmental disabilities than private practitioners. However, the three groups did not differ in educational experiences and attitudes concerning patients from different ethnic/racial groups. The better the respondents' graduate education about certain patient groups had been, the more positive were their attitudes and behavior. Conclusions: Improving endodontic residents' education about treating underserved patients is likely to improve their attitudes and behavior related to providing much-needed care for these patients. These findings are a call-toaction for dental educators to ensure quality education is being provided about these issues in order to decrease access to care problems for underserved patients.
\end{abstract}

Dr. Inglehart is Professor, Department of Periodontics and Oral Medicine, School of Dentistry, and Adjunct Professor of Psychology, Department of Psychology, College of Literature, Science, and Arts, University of Michigan; Mr. Schneider is Research Assistant, Department of Periodontics and Oral Medicine, School of Dentistry, University of Michigan; Dr. Bauer is Predoctoral Director of Endodontics, School of Dentistry, University of Michigan; Dr. Dharia is a dentist in private practice, Chicago, IL; and Dr. McDonald is Chair, Department of Endodontics, School of Dentistry, University of Michigan. Direct correspondence and requests for reprints to Dr. Marita R. Inglehart, School of Dentistry, University of Michigan, 1011 North University Ave., Ann Arbor, MI 48109-1078; 734-763-8073; mri@umich.edu.

Keywords: dental education, endodontics, endodontic graduate education, ethnic/racial minorities, underserved patients, socioeconomically disadvantaged patients, patients covered by Medicaid, patients with special health care needs, pro bono cases

Submitted for publication 6/14/13; accepted 8/13/13

I n 2000, the first-ever U.S. surgeon general's report on oral health drew attention to the fact that several groups of patients face challenges when seeking oral health care services. These underserved groups include patients from socioeconomically disadvantaged and/or minority populations as well as patients with special health care needs (SHCN) who are medically compromised or have disabilities. ${ }^{1}$ A variety of factors contribute to these overall access to dental care problems such as no inclusion of dental services for adult patients covered by Medicaid in some states, as well as low and inconsistent reimbursement rates for treatment provided for patients covered by Medicaid in other states. ${ }^{2}$ Although these challenges are serious issues in general, they become even more severe when these patients need specialty care such as endodontic treatment. A recent study showed, for example, that even the majority of dental schools reported that referrals for endodontic treatment for dental patients with urgent care needs occurred less than 25 percent of the time. ${ }^{3}$ The reasons for this situation were that 
the patients' financial situation led them to opt for extractions rather than expensive root canal therapy. Currently, Medicaid generally supports the extraction of teeth, while endodontic treatment is not covered by Medicaid in nearly all U.S. states. ${ }^{4}$ Extraction, rather than prevention-oriented dental care, is therefore the standard dental care for uninsured or underinsured adult dental patients, ${ }^{5}$ and as a result endodontic procedures have declined as a proportion of total dental procedures. ${ }^{6}$

In consideration of the simple fact that endodontic care offers the opportunity for patients to maintain their natural teeth in situations in which they would otherwise be extracted, ${ }^{7}$ it seems important to consider how current endodontists and future endodontists (i.e., current residents in endodontic graduate programs), as well as faculty members in these programs, perceive this situation. Specifically, it is of interest to consider how well endodontists have been or currently are being educated about providing care for these three groups of underserved patients, what attitudes they have, and how they behave professionally — or, in the case of residents, intend to behave in the future-in this context.

Previous research has shown that education of predoctoral dental students ${ }^{8-11}$ as well as residents in dental specialty programs $\mathrm{s}^{12,13}$ concerning care for underserved patients was clearly related to these future providers' professional attitudes and behavior. For example, when Dao et al. analyzed these issues for patients with SHCN, they found a significant relationship between how well dentists had been prepared by their predoctoral dental education to treat patients with SHCN and mental retardation/developmental disabilities and the variety of patients with SHCN for whom they provided services. ${ }^{8}$ Smith et al. found that dental students' behavioral intentions to treat patients covered by Medicaid or from minority populations were significantly related to the quality of their educational experiences related to providing care for these patients. ${ }^{9}$ Research with orthodontists and residents in orthodontic graduate programs,${ }^{13}$ as well as with periodontists and residents in periodontic graduate programs, ${ }^{12}$ also supported this general finding that the quality of education about providing care for these groups of underserved patients was significantly related to the professional attitudes and behavior of these providers.

These findings lead to the question whether similar relationships can be found in data collected from endodontists in private practice, faculty members, and residents in graduate endodontic programs.
The objectives of this study therefore were a) to explore endodontic residents', faculty members', and private practice endodontists' perceptions of their education about treating underserved patients, along with related attitudes and behavior, and b) to determine how their group-specific educational experiences were related to their specific attitudes and behavior concerning providing care for patients in each of these three groups.

\section{Materials and Methods}

This study was approved by the Institutional Review Board for the Behavioral and Health Sciences at the University of Michigan, Ann Arbor, Michigan. An a priori power analysis with the program package G*Power 3.1.2 (www.psycho.uni-duesseldorf.de/ abteilungen/aap/gpower3) was conducted to compute the needed sample size to test whether there were significant relationships between the quality of the educational experiences concerning the treatment of patients in each of the three groups of underserved patients and the respondents' attitudes and behavior/ behavioral intentions. Assuming that a t-test would be used to test this one-sided hypothesis, with alpha $=0.05$, the power $=0.80$, and a medium effect size of 0.30 , the results showed that a sample size of sixty-four respondents was needed. Correlations were computed based on data from seventy-eight endodontic residents and seventy-five endodontists in private practice.

The endodontic residents were recruited by sending individual emails to 327 graduate student members of the American Association of Endodontists (AAE). The same recruitment technique was used to contact 200 endodontic faculty members of the AAE. A random number list was used to randomly identify 433 endodontists in private practice who were AAE members (http://teorica.fis.ucm.es/ $\mathrm{ft} 8 /$ tablern2.pdf). The emails sent to residents, faculty members, and endodontists in private practice explained the study and its research objectives and asked recipients to respond anonymously using a web-link to an anonymous survey on the University of Michigan-UM Lessons website.

All three surveys consisted of four parts. Part I contained questions concerning the sociodemographic and educational characteristics of the respondents. The questions in Part II focused on how well the educational programs had prepared the respondents to treat patients from underserved populations such 
as patients with SHCN and developmental disabilities, patients from socioeconomically disadvantaged groups, patients covered by Medicaid, patients from different ethnic/racial groups, and patients who were treated as pro bono cases. Part III focused on assessing the respondents' attitudes towards providing care for these underserved groups, and Part IV consisted of questions concerning how likely the respondents were to treat patients from these different groups either at the current time or, for residents, after they graduated in the future. While residents and endodontists answered all the questions about the quality of their education, faculty members were only asked to assess the quality of the education their own program provides for their residents. They did not report the quality of their own personal education concerning these topics. The attitudinal and behaviorrelated questions were answered by respondents in all three groups. The answers to the educational questions and the questions related to attitudes and behavior/behavioral intentions were all Likert-style questions answered on five-point scales with $1=$ disagree strongly, $2=$ disagree, $3=$ =neutral, $4=$ agree, and $5=$ agree strongly. All questions were adapted from previous surveys with orthodontic and periodontic residents and endodontists. ${ }^{12-14}$
The data were analyzed with SPSS (Version 19). Descriptive statistics such as percentages, means, and standard deviations were computed to describe the responses. The average responses of the residents, faculty members, and endodontists were compared with analyses of variance. Pearson correlation coefficients were used to test relationships between the variables. A significance level of $p<0.05$ was assumed to be significant.

\section{Results}

Of the 327 contacted endodontics residents, seventy-eight responded (response rate: 24 percent). Of the 200 contacted faculty members, forty-eight responded (response rate: 24 percent). A total of seventy-five endodontists in private practice responded to the recruitment email (response rate: 17 percent of 433 AAE members contacted).

A description of the respondents' demographic and educational characteristics appears in Table 1. While most respondents in each of the three groups were male, residents and faculty members were more likely to be female compared to endodontists in private practice ( 32 percent $/ 26$ percent vs. 13 percent; $p=0.02$ ). On average, the graduate students

Table 1. Overview of respondents in study

\begin{tabular}{|c|c|c|c|c|}
\hline Variable & $\begin{array}{l}\text { Residents } \\
\mathrm{N}=78\end{array}$ & $\begin{array}{l}\text { Faculty Members } \\
\qquad \mathrm{N}=48\end{array}$ & $\begin{array}{l}\text { Private Practice Endodontists } \\
\qquad N=75\end{array}$ & $\mathrm{p}$ \\
\hline \multicolumn{5}{|l|}{ Gender } \\
\hline Male & $68 \%$ & $76 \%$ & $87 \%$ & 0.02 \\
\hline Female & $32 \%$ & $24 \%$ & $13 \%$ & \\
\hline \multicolumn{5}{|l|}{ Age } \\
\hline Mean & 32.53 years & 53.27 years & 47.58 years & $<0.001$ \\
\hline SD & 5.364 & 9.203 & 9.609 & \\
\hline Range & $25-52$ & $31-65$ & $31-69$ & \\
\hline \multicolumn{5}{|l|}{ Ethnicity } \\
\hline African American & $1 \%$ & $4 \%$ & $3 \%$ & 0.158 \\
\hline Asian American & $19 \%$ & $9 \%$ & $7 \%$ & \\
\hline European American & $69 \%$ & $82 \%$ & $86 \%$ & \\
\hline Hispanic/Latino & $5 \%$ & $2 \%$ & $4 \%$ & \\
\hline Other & $4 \%$ & $2 \%$ & 0 & \\
\hline No response & $2 \%$ & $1 \%$ & 0 & \\
\hline $\begin{array}{l}\text { Year in residency/number } \\
\text { years practiced }\end{array}$ & $\begin{array}{l}\% \text { in each year in } \\
\text { residency program }\end{array}$ & $\begin{array}{l}\text { Number years } \\
\text { practiced }\end{array}$ & $\begin{array}{l}\text { Number years } \\
\text { practiced }\end{array}$ & \\
\hline & Year $1: 1 \%$ & Mean=19.66 & Mean=15.04 & \\
\hline & Year 2: $82 \%$ & $\mathrm{SD}=9.38$ & $\mathrm{SD}=9.88$ & \\
\hline & Year 3: $17 \%$ & Range: 1-37 & Range: 1-38 & \\
\hline Number of graduate programs & 37 & 30 & 37 & \\
\hline
\end{tabular}


were thirty-three years of age, while the faculty members were an average of fifty-three years and the endodontists were an average of forty-eight years. In addition, in each of the three groups, the majority of respondents were from European American populations. On average, the faculty members had practiced about twenty years and the endodontists about fifteen years. Most of the graduate students were in the second year of their residency program. The graduate students were enrolled in thirty-seven programs, the faculty members had graduated from thirty endodontic graduate programs, and the endodontists had graduated from thirty-seven endodontic graduate programs.

Table 2 provides an overview of the residents' and endodontists' responses concerning their graduate dental education and how well they thought their classroom-based, clinical, and community-based graduate education had prepared them to treat patients from three underserved groups: patients from different ethnic/racial groups, patients covered by Medicaid or treated as pro bono cases, and patients with SHCN and developmental disabilities. Overall, large percentages of both the residents and endodontists reported that they disagreed strongly, disagreed, or were neutral concerning the statements that their programs had prepared them well to treat patients with these characteristics. The most positive evaluations were given both by residents and by endodontists for their educational experiences related to providing care for patients from different ethnic/racial groups. However, the average responses to all educational questions related to patients covered by Medicaid or pro bono patients and patients with SHCN and developmental disabilities showed that the residents answered more positively than the endodontists.

Table 3 provides an overview of the responses of residents, faculty members, and endodontists concerning their attitudes and professional behavior related to providing care for patients from these three underserved groups. These data show that attitudes and behavior/behavioral intentions towards patients from different ethnic/racial groups were rather positive. Respondents in all three categories agreed that they like to treat patients from different ethnic/racial groups. However, endodontists agreed slightly less with the statement "My patients are from all different ethnic/racial groups" than residents and faculty members. Residents on the other hand agreed less strongly that their future practices will include patients from ethnic/racial groups different from their own.
Compared to the attitudes towards patients from different ethnic/racial groups, both residents' and endodontists' attitudes towards patients from socioeconomically disadvantaged groups or patients with special needs were less positive. Endodontists had less positive attitudes towards patients covered by Medicaid, pro bono patients, and patients with SHCN and developmental disabilities than residents and faculty members. They also were significantly less confident about providing care for patients with developmental disabilities. However, their behavioral responses related to providing care for patients with SHCN and patients with developmental disabilities did not differ from the residents' behavioral intentions.

Table 4 shows the relationships between residents' and endodontists' educational experiences related to the three groups of underserved patients and their attitudes and behavior/behavioral intentions concerning treatment of these three patient groups. As predicted, the more positive the respondents' educational experiences were concerning patients from different ethnic/racial groups, the more positive were their attitudes towards these patients and their behavior/behavioral intentions. However, the responses concerning educational experiences related to patients covered by Medicaid and pro bono patients were only related - as predicted - to endodontists' attitudes towards pro bono patients. Finally, the respondents' educational experiences concerning patients with SHCN and patients with developmental disabilities were strongly related to their confidence in treating these patients as well as to their attitudes towards patients with SHCN. In the case of the endodontists, the educational experiences in this context were also strongly correlated with their attitudes towards patients with developmental disabilities. The residents' educational experiences with this group of underserved patients were significantly correlated with their behavioral intentions related to providing care for patients covered by Medicaid.

Table 5 shows the faculty members' evaluations of their predoctoral and graduate students' educational experiences concerning providing treatment for these three different patient groups at their institutions in classroom, clinic, and community settings. These data showed again that the educational experiences concerning patients from different ethnic/racial groups were perceived as consistently positive. In addition, the educational experiences concerning patients covered by Medicaid and pro bono patients of both predoctoral and graduate students were quite 
Table 2. Residents' and private practice endodontists' perceptions of their graduate education in preparing them to treat patients with various characteristics, by percentage of respondents in each category

\begin{tabular}{|c|c|c|c|c|c|}
\hline & Respondents & $1 / 2$ & 3 & $4 / 5$ & Mean \\
\hline \multicolumn{6}{|l|}{ Patients from Different Ethnic/Racial Groups } \\
\hline \multirow{2}{*}{$\begin{array}{l}\text { My classroom-based education prepared me well to } \\
\text { treat patients from different ethnic/racial groups. }\end{array}$} & Residents & $1 \% / 5 \%$ & $31 \%$ & $28 \% / 34 \%$ & 3.88 \\
\hline & Endodontists & $1 \% / 8 \%$ & $35 \%$ & $27 \% / 28 \%$ & 3.73 \\
\hline \multirow{3}{*}{$\begin{array}{l}\text { My clinical education prepared me well to treat } \\
\text { patients from different ethnic/racial groups. }\end{array}$} & Residents & $0 / 1 \%$ & $23 \%$ & $34 \% / 42 \%$ & 4.16 \\
\hline & Endodontists & $1 \% / 3 \%$ & $30 \%$ & $38 \% / 28 \%$ & 3.89 \\
\hline & & & & & $* * * *$ \\
\hline \multirow{2}{*}{$\begin{array}{l}\text { My community-based education prepared me well } \\
\text { to treat patients from different ethnic/racial groups. }\end{array}$} & Residents & $3 \% / 1 \%$ & $40 \%$ & $32 \% / 25 \%$ & 3.74 \\
\hline & Endodontists & $3 \% / 4 \%$ & $41 \%$ & $28 \% / 24 \%$ & 3.66 \\
\hline \multicolumn{6}{|l|}{ Patients Covered by Medicaid and Pro Bono Patients } \\
\hline \multirow{3}{*}{$\begin{array}{l}\text { My classroom-based education prepared me well to } \\
\text { treat patients covered by Medicaid. }\end{array}$} & Residents & $3 \% / 8 \%$ & $39 \%$ & $28 \% / 22 \%$ & 3.58 \\
\hline & Endodontists & $12 \% / 15 \%$ & $53 \%$ & $16 \% / 4 \%$ & 2.85 \\
\hline & & & & & $* * *$ \\
\hline \multirow{3}{*}{$\begin{array}{l}\text { My classroom-based education prepared me well to } \\
\text { treat patients as pro bono cases. }\end{array}$} & Residents & $4 \% / 10 \%$ & $41 \%$ & $28 \% / 18 \%$ & 3.46 \\
\hline & Endodontists & $12 \% / 12 \%$ & $49 \%$ & $22 \% / 5 \%$ & 2.96 \\
\hline & & & & & $* *$ \\
\hline \multirow{3}{*}{$\begin{array}{l}\text { My clinical education prepared me well to treat } \\
\text { patients covered by Medicaid. }\end{array}$} & Residents & $4 \% / 4 \%$ & $26 \%$ & $34 \% / 32 \%$ & 3.86 \\
\hline & Endodontists & $6 \% / 14 \%$ & $50 \%$ & $21 \% / 10 \%$ & 3.15 \\
\hline & & & & & $* * *$ \\
\hline \multirow{3}{*}{$\begin{array}{l}\text { My clinical education prepared me well to treat } \\
\text { patients as pro bono cases. }\end{array}$} & Residents & $3 \% / 4 \%$ & $36 \%$ & $34 \% / 23 \%$ & 3.71 \\
\hline & Endodontists & $3 \% / 21 \%$ & $47 \%$ & $25 \% / 6 \%$ & 3.10 \\
\hline & & & & & $* * *$ \\
\hline \multirow{3}{*}{$\begin{array}{l}\text { My community-based education prepared me well } \\
\text { to treat patients covered by Medicaid. }\end{array}$} & Residents & $4 \% / 1 \%$ & $44 \%$ & $33 \% / 17 \%$ & 3.57 \\
\hline & Endodontists & $10 \% / 14 \%$ & $50 \%$ & $19 \% / 7 \%$ & 3.00 \\
\hline & & & & & $* * *$ \\
\hline \multirow{3}{*}{$\begin{array}{l}\text { My community-based education prepared me well } \\
\text { to treat patients as pro bono cases }\end{array}$} & Residents & $3 \% / 4 \%$ & $51 \%$ & $29 \% / 14 \%$ & 3.47 \\
\hline & Endodontists & $7 \% / 11 \%$ & $47 \%$ & $23 \% / 10 \%$ & 3.17 \\
\hline & & & & & $* * * *$ \\
\hline \multicolumn{6}{|c|}{ Patients with Special Health Care Needs (SHCN) and Developmental Disabilities } \\
\hline \multirow{3}{*}{$\begin{array}{l}\text { My classroom-based education prepared me well to } \\
\text { treat patients with SHCN. }\end{array}$} & Residents & $7 \% / 22 \%$ & $26 \%$ & $38 \% / 7 \%$ & 3.16 \\
\hline & Endodontists & $11 \% / 34 \%$ & $32 \%$ & $22 \% / 1 \%$ & 2.69 \\
\hline & & & & & $* *$ \\
\hline \multirow{2}{*}{$\begin{array}{l}\text { My classroom-based education prepared me well to } \\
\text { treat patients with developmental disabilities. }\end{array}$} & Residents & $8 \% / 26 \%$ & $34 \%$ & $27 \% / 5 \%$ & 2.96 \\
\hline & Endodontists & $15 \% / 34 \%$ & $32 \%$ & $18 \% / 1 \%$ & $\begin{array}{c}2.57 \\
*\end{array}$ \\
\hline \multirow{2}{*}{$\begin{array}{l}\text { My clinical education prepared me well to treat } \\
\text { patients with SHCN. }\end{array}$} & Residents & $7 \% / 14 \%$ & $26 \%$ & $41 \% / 12 \%$ & 3.38 \\
\hline & Endodontists & $10 \% / 28 \%$ & $24 \%$ & $28 \% / 10 \%$ & 3.00 \\
\hline \multirow{3}{*}{$\begin{array}{l}\text { My clinical education prepared me well to treat } \\
\text { patients with developmental disabilities. }\end{array}$} & Residents & $7 \% / 18 \%$ & $24 \%$ & $39 \% / 12 \%$ & 3.32 \\
\hline & Endodontists & $11 \% / 26 \%$ & $39 \%$ & $15 \% / 8 \%$ & 2.83 \\
\hline & & & & & \\
\hline \multirow{2}{*}{$\begin{array}{l}\text { My community-based education prepared me well } \\
\text { to treat patients with SHCN. }\end{array}$} & Residents & $7 \% / 10 \%$ & $48 \%$ & $26 \% / 10 \%$ & 3.22 \\
\hline & Endodontists & $10 \% / 21 \%$ & $46 \%$ & $19 \% / 4 \%$ & $\begin{array}{c}2.88 \\
*\end{array}$ \\
\hline \multirow{2}{*}{$\begin{array}{l}\text { My community-based education prepared me well } \\
\text { to treat patients with developmental disabilities. }\end{array}$} & Residents & $7 \% / 12 \%$ & $45 \%$ & $25 \% / 11 \%$ & 3.21 \\
\hline & Endodontists & $11 \% / 17 \%$ & $49 \%$ & $20 \% / 3 \%$ & $\begin{array}{c}2.86 \\
*\end{array}$ \\
\hline
\end{tabular}

${ }^{*} \mathrm{p}<0.05 ;{ }^{* *} \mathrm{p}<0.01 ;{ }^{* * *} \mathrm{p}<0.001 ; * * * * \mathrm{p}<0.10$

Note: Responses were given on five-point answer scales with $1=$ disagree strongly, $2=$ disagree, $3=$ neutral, $4=$ agree, and $5=$ agree strongly. Percentages may not total $100 \%$ because of rounding. 
positive in all settings. However, the faculty respondents reported believing that their graduate students received a significantly better education about treating patients with SHCN and developmental disabilities than their predoctoral students, both in the classroom and the clinic setting. Overall, the faculty members were neutral to positive in their evaluations of their students' educational experiences concerning these three groups of underserved patients.

\section{Discussion}

Previous research has shown that the quality of dental education concerning care for underserved

Table 3. Responses concerning attitudes and behavior related to treating underserved patients, by percentage of respondents in each category

\begin{tabular}{|c|c|c|c|c|c|}
\hline & Respondents & $1 / 2$ & 3 & $4 / 5$ & Mean \\
\hline \multicolumn{6}{|l|}{ Patients from Different Ethnic/Racial Groups } \\
\hline $\begin{array}{l}\text { I like to treat patients from different ethnic/racial } \\
\text { groups. }\end{array}$ & $\begin{array}{l}\text { Residents } \\
\text { Faculty } \\
\text { Endodontists }\end{array}$ & $\begin{array}{c}0 / 0 \\
0 / 2 \% \\
3 \% / 0\end{array}$ & $\begin{array}{l}31 \% \\
18 \% \\
25 \%\end{array}$ & $\begin{array}{l}33 \% / 36 \% \\
31 \% / 49 \% \\
37 \% / 35 \%\end{array}$ & $\begin{array}{l}4.05 \\
4.27 \\
4.01\end{array}$ \\
\hline $\begin{array}{l}\text { My patients are from all different ethnic/racial } \\
\text { groups. }\end{array}$ & $\begin{array}{l}\text { Residents } \\
\text { Faculty } \\
\text { Endodontists }\end{array}$ & $\begin{array}{c}0 / 0 \\
0 / 0 \\
4 \% / 3 \%\end{array}$ & $\begin{array}{l}1 \% \\
4 \% \\
1 \%\end{array}$ & $\begin{array}{l}33 \% / 65 \% \\
33 \% / 63 \% \\
41 \% / 51 \%\end{array}$ & $\begin{array}{c}4.64 \\
4.59 \\
4.32 *\end{array}$ \\
\hline $\begin{array}{l}\text { My practice will include patients from ethnic/racial } \\
\text { groups different from my own. }\end{array}$ & $\begin{array}{l}\text { Residents } \\
\text { Endodontists }\end{array}$ & $\begin{array}{l}8 \% / 19 \% \\
4 \% / 1 \%\end{array}$ & $\begin{array}{c}45 \% \\
1 \%\end{array}$ & $\begin{array}{l}19 \% / 10 \% \\
39 \% / 54 \%\end{array}$ & $\begin{array}{c}3.03 \\
4.38 \\
* * *\end{array}$ \\
\hline $\begin{array}{l}\text { I will treat patients from ethnic/racial groups differ- } \\
\text { ent from my own. }\end{array}$ & Residents & $0 / 0$ & $5 \%$ & $38 \% / 57 \%$ & 4.51 \\
\hline
\end{tabular}

\section{Patients Covered by Medicaid and Pro Bono Patients \\ I like to treat patients covered by Medicaid.}

$\begin{array}{lcccc}\text { Residents } & 16 \% / 22 \% & 35 \% & 18 \% / 10 \% & 3.46 \\ \text { Endodontists } & 28 \% / 28 \% & 34 \% & 4 \% / 5 \% & 2.30 * * \\ \text { Residents } & 4 \% / 6 \% & 25 \% & 41 \% / 25 \% & 3.77 \\ \text { Faculty } & 0 / 20 \% & 33 \% & 27 \% / 20 \% & 3.47 \\ \text { Endodontists } & 8 \% / 19 \% & 39 \% & 31 \% / 3 \% & 3.01^{* * *} \\ \text { Residents } & 7 \% / 8 \% & 35 \% & 32 \% / 18 \% & 3.74\end{array}$

I will treat patients covered by Medicaid.

Residents $\quad 7 \% / 8 \%$

\section{Patients with Special Health Care
I like to treat patients with $\mathrm{SHCN}$.}

I like to treat patients with developmental disabilities.

I am confident treating patients with $\mathrm{SHCN}$.

I am confident treating patients with developmental disabilities.

I will/treat patients with SHCN.

I will/treat patients with developmental disabilities.

${ }^{*} \mathrm{p}<0.05 ;{ }^{* *} \mathrm{p}<0.01 ;{ }^{* * *} \mathrm{p}<0.001$

$\begin{array}{lcccc}\text { Residents } & 8 \% / 7 \% & 55 \% & 28 \% / 3 \% & 3.11 \\ \text { Faculty } & 0 / 11 \% & 48 \% & 28 \% / 13 \% & 3.44 \\ \text { Endodontists } & 5 \% / 23 \% & 56 \% & 15 \% / 1 \% & 2.84 * * * \\ \text { Residents } & 10 \% / 14 \% & 54 \% & 16 \% / 7 \% & 2.97 \\ \text { Faculty } & 0 / 16 \% & 56 \% & 22 \% / 7 \% & 3.20 \\ \text { Endodontists } & 9 \% / 32 \% & 51 \% & 8 \% / 0 & 2.57 * * * \\ \text { Residents } & 0 / 12 \% & 27 \% & 55 \% / 6 \% & 3.53 \\ \text { Faculty } & 0 / 4 \% & 30 \% & 48 \% / 17 \% & 3.78 \\ \text { Endodontists } & 3 \% / 16 \% & 16 \% & 55 \% / 11 \% & 3.78 \\ \text { Residents } & 1 \% / 15 \% & 37 \% & 42 \% / 5 \% & 3.35 \\ \text { Faculty } & 0 / 7 \% & 40 \% & 40 \% / 13 \% & 3.60 \\ \text { Endodontists } & 7 \% / 24 \% & 23 \% & 41 \% / 5 \% & 3.15 * \\ \text { Residents } & 0 / 5 \% & 20 \% & 57 \% / 17 \% & 3.87 \\ \text { Faculty } & 0 / 4 \% & 22 \% & 51 \% / 22 \% & 3.91 \\ \text { Residents } & 1 \% / 15 \% & 37 \% & 42 \% / 5 \% & 3.35 \\ \text { Faculty } & 0 / 7 \% & 27 \% & 57 \% / 11 \% & 3.71\end{array}$

Note: Responses were given on five-point answer scales with $1=$ disagree strongly, $2=$ disagree, $3=$ neutral, $4=$ agree, and $5=$ agree strongly. Percentages may not total $100 \%$ because of rounding. 
patients in the United States and the attitudes and behaviors of general dentists ${ }^{8-10}$ as well as periodontists $^{12}$ and orthodontists ${ }^{13,14}$ were clearly related. The better predoctoral and postdoctoral dental students were educated about providing care for patients with SHCN and patients from disadvantaged and/or minority populations, the more positive their attitudes towards these patients were and the more likely they were to actually include these patients among their patient families. The question is whether these relationships can also be found among endodontic residents, faculty members, and endodontists.
Overall, the data from our study showed that neither endodontists nor residents agreed on average that their classroom, clinic, and community-based education had prepared them well to treat patients with special health care needs or developmental disabilities. While the responses were slightly more positive concerning their education about patients covered by Medicaid and patients treated as pro bono cases and even more positive concerning educational experiences with patients from different ethnic/racial groups, educational improvements are definitely possible. One might argue that these improvements

Table 4. Relationships (Pearson correlations) between residents' and private practice endodontists' educational experiences and their attitudes and behavior concerning providing care for underserved patients

\begin{tabular}{|c|c|c|c|c|}
\hline & \multirow[b]{2}{*}{ Respondents } & \multicolumn{3}{|c|}{ Education Concerning Patients With/From } \\
\hline & & $\begin{array}{l}\text { Different Ethnic/ } \\
\text { Racial Groups }\end{array}$ & $\begin{array}{l}\text { Medicaid/Pro } \\
\text { Bono Patients }\end{array}$ & $\begin{array}{l}\text { SHCN/Developmental } \\
\text { Disabilities }\end{array}$ \\
\hline \multicolumn{5}{|l|}{$\begin{array}{l}\text { Attitudes } \\
\text { I like to treat patients: }\end{array}$} \\
\hline from different ethnic/racial groups. & $\begin{array}{l}\text { Residents } \\
\text { Endodontists }\end{array}$ & $\begin{array}{c}0.45^{* * *} \\
0.35^{* *}\end{array}$ & $\begin{array}{c}0.28^{*} \\
0.11\end{array}$ & $\begin{array}{c}0.13 \\
-0.06\end{array}$ \\
\hline covered by Medicaid. & $\begin{array}{l}\text { Residents } \\
\text { Endodontists }\end{array}$ & $\begin{array}{l}0.29 * \\
-0.09\end{array}$ & $\begin{array}{l}0.21^{* * * *} \\
0.19\end{array}$ & $\begin{array}{l}0.21^{* * * *} \\
0.01\end{array}$ \\
\hline pro bono patients. & $\begin{array}{l}\text { Residents } \\
\text { Endodontists }\end{array}$ & $\begin{array}{l}0.13 \\
0.14\end{array}$ & $\begin{array}{c}0.07 \\
0.37^{* *}\end{array}$ & $\begin{array}{l}0.22^{* * * *} \\
0.15\end{array}$ \\
\hline with SHCN. & $\begin{array}{l}\text { Residents } \\
\text { Endodontists }\end{array}$ & $\begin{array}{l}0.19 \\
0.07\end{array}$ & $\begin{array}{c}0.06 \\
0.24^{*}\end{array}$ & $\begin{array}{l}0.32 * * \\
0.30^{*}\end{array}$ \\
\hline with developmental disabilities. & $\begin{array}{l}\text { Residents } \\
\text { Endodontists }\end{array}$ & $\begin{array}{c}0.04 \\
-0.03\end{array}$ & $\begin{array}{c}0.14 \\
0.21^{* * * *}\end{array}$ & $\begin{array}{c}0.02 \\
0.41^{* * *}\end{array}$ \\
\hline \multicolumn{5}{|l|}{ Behavior/Behavioral Intentions } \\
\hline $\begin{array}{l}\text { My patients are from all ethnic/racial } \\
\text { groups. }\end{array}$ & $\begin{array}{l}\text { Residents } \\
\text { Endodontists }\end{array}$ & $\begin{array}{l}0.25^{*} \\
0.24^{*}\end{array}$ & $\begin{array}{l}0.11 \\
-0.07\end{array}$ & $\begin{array}{c}0.04 \\
-0.06\end{array}$ \\
\hline $\begin{array}{l}\text { My practice includes/will include pa- } \\
\text { tients from all ethnic/racial groups. }\end{array}$ & $\begin{array}{l}\text { Residents } \\
\text { Endodontists }\end{array}$ & $\begin{array}{l}0.31^{* *} \\
0.32^{* *}\end{array}$ & $\begin{array}{l}0.25 \\
0.03\end{array}$ & $\begin{array}{c}0.24^{*} \\
0.01\end{array}$ \\
\hline \multicolumn{5}{|l|}{ I will treat patients: } \\
\hline covered by Medicaid. & Residents & 0.18 & 0.11 & $0.28^{*}$ \\
\hline with SHCN. & Residents & 0.15 & $0.20 * * * *$ & 0.03 \\
\hline with developmental disabilities. & Residents & -0.04 & -0.04 & -0.05 \\
\hline \multicolumn{5}{|l|}{ I am confident treating patients with: } \\
\hline SHCN. & $\begin{array}{l}\text { Residents } \\
\text { Endodontists }\end{array}$ & $\begin{array}{r}0.14 \\
-0.12\end{array}$ & $\begin{array}{l}0.21^{* * * * *} \\
0.08\end{array}$ & $\begin{array}{l}0.45^{* * *} \\
0.39 * * *\end{array}$ \\
\hline developmental disabilities. & $\begin{array}{l}\text { Residents } \\
\text { Endodontists }\end{array}$ & $\begin{array}{r}0.19 \\
-0.12\end{array}$ & $\begin{array}{c}0.27^{*} \\
0.16\end{array}$ & $\begin{array}{l}0.41^{* * *} \\
0.52^{* * *}\end{array}$ \\
\hline
\end{tabular}

${ }^{*} \mathrm{p}<0.05 ;{ }^{* *} \mathrm{p}<0.01 ;{ }^{* * *} \mathrm{p}<0.001 ;{ }^{* * * *} \mathrm{p}<0.10$

Note: Responses were given on five-point answer scales with $1=$ disagree strongly, $2=$ disagree, $3=$ neutral, $4=$ agree, and $5=$ agree strongly. Indices were created by averaging the responses to the statements concerning classroom-based, clinical, and community-based education of patients a) from different ethnic/racial groups, b) covered by Medicaid and pro bono patients, and c) patients with special health care needs $(\mathrm{SHCN})$ and developmental disabilities. 
are already in progress, given that the residents' responses were, on average, more positive than the clinicians' responses in most cases. The only exception is the comparison of responses concerning providing care for patients from different ethnic/racial groups, for which both groups gave equally positive answers.

It is interesting that a similar pattern of responses was found by Brown and Inglehart ${ }^{13}$ in their study of orthodontic residents and orthodontists and by Garfinkle et al. ${ }^{12}$ who surveyed residents in periodontal residency programs and periodontists. In both studies, educational experiences with providing care for patients from different ethnic/racial groups were evaluated most positively - as was the case in our study. In addition, those authors also reported the positive trend that residents described their experiences more positively than clinicians for most patient groups.

Table 5. Faculty members' responses concerning their programs' education about providing care for underserved patients

\begin{tabular}{|c|c|c|c|c|c|}
\hline & Students & $1 / 2$ & 3 & $4 / 5$ & Mean \\
\hline \multicolumn{6}{|l|}{ Patients from Different Ethnic/Racial Groups } \\
\hline \multirow{2}{*}{$\begin{array}{l}\text { Our classroom education prepares well to treat patients } \\
\text { from different ethnic/racial groups. }\end{array}$} & Predoc & $0 / 11 \%$ & $18 \%$ & $48 \% / 23 \%$ & 3.82 \\
\hline & Grad & $0 / 9 \%$ & $14 \%$ & $34 \% / 43 \%$ & $4.11^{* *}$ \\
\hline \multirow{2}{*}{$\begin{array}{l}\text { Our clinical education prepares well to treat patients from } \\
\text { different ethnic/racial groups. }\end{array}$} & Predoc & $0 / 5 \%$ & $21 \%$ & $36 \% / 39 \%$ & 4.09 \\
\hline & Grad & $0 / 5 \%$ & $9 \%$ & $37 \% / 49 \%$ & 4.30 \\
\hline \multirow{2}{*}{$\begin{array}{l}\text { Our community-based education prepares well to treat } \\
\text { patients from different ethnic/racial groups. }\end{array}$} & Predoc & $0 / 5 \%$ & $14 \%$ & $38 \% / 43 \%$ & 4.19 \\
\hline & Grad & $0 / 10 \%$ & $10 \%$ & $40 \% / 40 \%$ & 4.10 \\
\hline
\end{tabular}

\section{Patients Covered by Medicaid and Pro Bono Patients}

Our classroom education prepares well to treat patients covered by Medicaid.

Our classroom education prepares well to treat patients as pro bono cases.

Our clinical education prepares well to treat patients covered by Medicaid.

Our clinical education prepares well to treat patients as pro bono cases.

Our community-based education prepares well to treat patients covered by Medicaid.

Our community-based education prepares well to treat patients as pro bono cases.

\begin{tabular}{lcccc} 
Predoc & $2 \% / 9 \%$ & $34 \%$ & $41 \% / 14 \%$ & 3.55 \\
Grad & $2 \% / 9 \%$ & $23 \%$ & $34 \% / 32 \%$ & 3.84 \\
Predoc & $0 / 18 \%$ & $48 \%$ & $27 \% / 7 \%$ & 3.23 \\
Grad & $0 / 16 \%$ & $43 \%$ & $21 \% / 21 \%$ & 3.45 \\
Pre-doc & $2 \% / 7 \%$ & $28 \%$ & $40 \% / 23 \%$ & 3.74 \\
Grad & $2 \% / 7 \%$ & $18 \%$ & $36 \% / 36 \%$ & 3.98 \\
Predoc & $2 \% / 18 \%$ & $41 \%$ & $25 \% / 14 \%$ & 3.30 \\
Grad & $2 \% / 11 \%$ & $46 \%$ & $21 \% / 21 \%$ & 3.45 \\
Predoc & $0 / 5 \%$ & $14 \%$ & $48 \% / 33 \%$ & 4.10 \\
Grad & $0 / 10 \%$ & $10 \%$ & $40 \% / 40 \%$ & 4.10 \\
Predoc & $5 \% / 5 \%$ & $46 \%$ & $27 \% / 18 \%$ & 3.50 \\
Grad & $0 / 10 \%$ & $40 \%$ & $30 \% / 20 \%$ & 3.60 \\
\hline Predoc & $0 / 25 \%$ & $32 \%$ & $39 \% / 5 \%$ & 3.23 \\
Grad & $0 / 14 \%$ & $23 \%$ & $41 \% / 23 \%$ & $3.73 *$ \\
Predoc & $0 / 27 \%$ & $36 \%$ & $34 \% / 2 \%$ & 3.11 \\
Grad & $0 / 14 \%$ & $23 \%$ & $40 \% / 23 \%$ & $3.72 *$ \\
Predoc & $0 / 25 \%$ & $27 \%$ & $43 \% / 5 \%$ & 3.27 \\
Grad & $0 / 5 \%$ & $25 \%$ & $48 \% / 23 \%$ & $3.89 *$ \\
Predoc & $0 / 25 \%$ & $34 \%$ & $39 \% / 2 \%$ & 3.18 \\
Grad & $0 / 5 \%$ & $26 \%$ & $47 \% / 23 \%$ & $3.88 *$ \\
Predoc & $0 / 24 \%$ & $29 \%$ & $38 \% / 10 \%$ & 3.33 \\
Grad & $0 / 20 \%$ & $10 \%$ & $50 \% / 20 \%$ & 3.70 \\
Predoc & $0 / 24 \%$ & $29 \%$ & $38 \% / 10 \%$ & 3.33 \\
Grad & $0 / 10 \%$ & $10 \%$ & $60 \% / 20 \%$ & 3.90
\end{tabular}

\section{Patients with Special Health Care Needs (SHCN) and Developmental Disabilities}

Our classroom education prepares well to treat patients with SHCN.

Our classroom education prepares well to treat patients with developmental disabilities.

Our clinical education prepares well to treat patients with SHCN.

Our clinical education prepares well to treat patients with developmental disabilities.

Our community-based education prepares well to treat patients with SHCN.

Our community-based education prepares well to treat patients with developmental disabilities.

${ }^{*} \mathrm{p}<0.001 ;{ }^{*} \mathrm{p}<0.10$
Note: Responses were given on five-point answer scales with $1=$ disagree strongly, $2=$ disagree, $3=$ neutral, $4=$ agree, and $5=$ agree strongly. Percentages may not total $100 \%$ because of rounding. 
While Brown and Inglehart ${ }^{13,14}$ and Garfinkle et al. ${ }^{12}$ did not collect data from faculty members in their respective fields, our study was designed to include these responses. The comparisons of the attitudes and behavior of the three groups of respondents in this study were therefore quite interesting. The fact that faculty members had the most positive attitudes and behavior concerning providing care for patients with SHCN and with developmental disabilities is promising. However, the most positive attitudes and behavioral responses in all three groups were provided to the statements related to providing care for patients from different ethnic/racial populations. Overall, these findings might indicate that U.S. society might be moving into a postracial era.

The most important finding, however, might be that there were clear relationships between the quality of residents' and clinicians' educational experiences with these specific underserved patient groups and their attitudes as well as their behavior related to providing care for these groups. While previous studies had provided support for this relationship in the context of predoctoral dental education as well as in orthodontic and periodontic graduate education programs, it is important for dental educators in endodontic graduate programs to realize that this relationship is also found in their own field.

Finally, the endodontic faculty members' evaluations of the quality of their own programs' educational activities in this context were on average neutral to positive. However, they evaluated their predoctoral educational efforts related to providing care for patients with SHCN and patients with developmental disabilities less positively than their graduate education efforts. This finding is interesting because the Commission on Dental Accreditation's Standard 2-26, introduced in July 2004, states that "Graduates must be competent in assessing the treatment needs of patients with special needs." 15 This accreditation standard requires dental schools to ensure that curricular efforts are focusing on educating their students about patients with developmental disabilities, complex medical problems, significant physical limitations, and other special needs, though the question remains about how dental schools have responded to this standard.

This study has three limitations. First, the response rates were rather low, even though the absolute numbers of responses were sufficient to have the power to compare the answers of the members of the three groups and test the main hypothesis of interest concerning relationships between education and attitudes and behavior. This relatively low response rate might be due to the fact that the data were collected with a web-based survey. Sheehan showed in 2006 that one major problem of web-based surveys is a low response rate and that the response rates to electronic surveys have declined over the past years considerably. ${ }^{16}$ More recently, Hardigan et al. ${ }^{17}$ compared response rates to surveys that were mailed to those electronically accessible for practicing dentists and found that while electronic surveys were 2.68 times more cost-effective than mailed surveys, the response rates were far better for mailed surveys ( 28 percent) than for web-based surveys (11 percent). Additionally, when given an option to complete a survey online or by mail, dentists clearly preferred responding via postal mail ( 94 percent) versus online ( 6 percent) ${ }^{17}$ In consideration of the results of these two studies, the response rates to our web-based surveys were actually quite positive.

One might, however, argue that this relatively low response rate might indicate that a self-selection of respondents took place. Specifically, it could be possible that respondents with more positive attitudes towards these issues would be more likely to respond. In response to this potential limitation, one could argue that the same bias might have occurred among all three groups of respondents, thus making the group comparisons possible. However, caution should be used when analyzing the degree of disagreement/ agreement with certain items.

A third limitation would be that data were only collected with a survey and not by analyzing more objective data such as a curriculum review or data from patients' chart reviews in actual endodontic practices. Future research could focus on collecting these types of data.

\section{Conclusion}

Based on the data from this study, the following conclusions can be drawn. First, educational experiences related to providing care for underserved patients in endodontic graduate programs can still be improved. The fact that residents' evaluations were more positive than those of endodontists in private practice suggests that changes have been occurring. In addition, faculty members' positive responses could be an indicator of their willingness to address these issues in their teaching. Second, patients from different ethnic/racial populations might not encounter as many challenges in the future as they 
encountered in the past ${ }^{1}$ because all the respondents' educational experiences as well as attitudes were rather positive. Third, the fact that educational experiences and attitudes and behavior related to providing care for underserved patients were clearly related emphasizes the importance of dental educators' accepting responsibility to improve educational efforts related to providing care for underserved patients in both predoctoral and residency programs.

\section{REFERENCES}

1. Oral health in America: a report of the surgeon general. Rockville, MD: U.S. Department of Health and Human Services, National Institute of Dental and Craniofacial Research, National Institutes of Health, 2000.

2. Patrick D, Lee R, Nucci M, et al. Reducing oral health disparities: a focus on social and cultural determinants. BMC Oral Health 2006;6(Suppl 1):S4.

3. Tiwana KK, Hammersmith KJ, Murrah VA. Urgent care in the dental school setting: analysis of current environment and future challenges in emergency dental education. $\mathrm{J}$ Dent Educ 2007;71(3):331-8.

4. Centers for Medicare and Medicaid Services. Medicaid/ CHIP oral health services: fact sheet. October 2010. At: www.medicaid.gov/Medicaid-CHIP-Program-Information/By-Topics/Benefits/Downloads/2010-DentalFactsheet.pdf. Accessed: June 14, 2013.

5. Flaer PJ, Younis MZ, Benjamin PL, Hajeri Maha. A psychosocial approach to dentistry for the underserved: incorporating theory into practice. J Health Care Finance 2010;37(1):101-8.

6. Manski RJ, Moeller JF. Use of dental services: an analysis of visits, procedures, and providers, 1996. J Am Dent Assoc 2002;133(2):167-75.
7. Vargas CM, Arevalo O. How dental care can preserve and improve oral health. Dent Clin North Am 2009;53(3):399420.

8. Dao LP, Zwetchkenbaum S, Inglehart MR. General dentists and special needs patients: does dental education matter? J Dent Educ 2005;69(10):1107-15.

9. Smith CS, Ester TV, Inglehart MR. Dental education and care for underserved patients: an analysis of students' intentions and alumni behavior. J Dent Educ 2006;70(4):398-408.

10. Rich JP 3rd, Straffon L, Inglehart MR. General dentists and pediatric dental patients: the role of dental education. J Dent Educ 2006;70(12):1308-15.

11. Valentine AE, Inglehart MR. Medicaid patients in dental school clinics: do personal and professional experiences matter? J Dent Educ 2011;75(9):1225-35.

12. Garfinkle AJ, Richards PS, Inglehart MR. Providing care for underserved patients: periodontists' and periodontal residents' educational experiences, attitudes, and behavior. J Periodontol 2010;81(11):1-9.

13. Brown B, Inglehart MR. Orthodontic care for underserved patients: professional attitudes and behaviors of orthodontic residents and orthodontists. Angle Orthod 2011;81(6):1090-6.

14. Brown BR, Inglehart MR. Orthodontists' and orthodontic residents' education about treating underserved patients: effects on professional attitudes and behavior. J Dent Educ 2009;73(5):550-62.

15. Commission on Dental Accreditation. Accreditation standards for dental education programs. Chicago: American Dental Association, 2004.

16. Sheehan KB. E-mail survey response rates: a review. J Comput Mediat Comm 2006;6(2):1-38.

17. Hardigan PC, Succar CT, Fleisher JM. An analysis of response rate and economic costs between mail and webbased surveys among practicing dentists: a randomized trial. J Comm Health 2012;37(2):383-94. 